\title{
ФОТОАКТИВНІСТЬ БІОЛОГІЧНИХ МОЛЕКУЛ ЯК МОЖЛИВИЙ ФАКТОР КОРЕГУВАННЯ ТРИГЕРЗАЛЕЖНИХ СИСТЕМНИХ ПРОЦЕСІВ (ПЕРШЕ ПОВІДОМЛЕННЯ)
}

\author{
О. П. Мінцер, Д. В. Ватліцов
}

Національна медична академія післядипломної освіти імені П. Л. Шупика

\begin{abstract}
Застосування нового системного підходу до розгляду проблем регуляції та концептуального впливу на певні ланки створює умови для накопичення та врахування всіх відомих результатів численних досліджень. Перегляд мішеней електромагнітного опромінення УФ, видимого та 14 спектрів із застосуванням інструменттів системної біології визначає механізми корекції внутрішньоклітинних системних процесів. Метою даної роботи було формування концепції фотоактивації тригерних біомолекул живої клітини як фактора корегування внутрішньоклітинних системних процесів. Застосовувався контент-аналіз, коллокейт аналіз та дані, отримані з бази відомих та передбачуваних взаємодій біомолекул. Було виокремлено чотири результуючі фотоактивації світлом видимого діапазону тригерзалежних системних процесів живої клітини: співрозмірність тригерів з довжиною хвилі; частотно-резонансна активація/деактивація; обумовлене поляризацією зростання енергії світлового потоку; асиметрична відповідь живих систем. Показано, що фізико-хімічні особливості біополімерів обумовлюють можливість проведення корекції тригерзалежних процесів, а асиметричність відповіді живих систем сумарно зі збільшенням надходження до системи енергії приводить до активації механізмів, направлених на виживання.
\end{abstract}

Ключові слова: тригер, системна біологія, асиметрія, електромагнітне випромінювання, мішень.

\section{ФОТОАКТИВНОСТЬ БИОЛОГИЧЕСКИХ МОЛЕКУЛ КАК ВОЗМОЖНЫЙ ФАКТОР КОРРЕКТИРОВАНИЯ ТРИГГЕРЗАВИСИМЫХ СИСТЕМНЫХ ПРОЦЕССОВ (ПЕРВОЕ СООБЩЕНИЕ)}

\begin{abstract}
О. П. Минцер, Д. В. Ватлицов
Национальная медицинская академия последипломного образования имени П. Л. Шупика

Применение нового системного подхода к рассмотрению проблем регуляции и концептуального влияния на определенные звенья создает условия для накопления и учета всех известных результатов многочисленных исследований. Просмотр мишеней электромагнитного облучения УФ, видимого и ИК спектров с применением инструментов системной биологии определяет механизмы коррекции внутриклеточных системных процессов. Целью данной работы было формирование концепции фотоактивации триггерных биомолекул живой клетки как фактора корректировки внутриклеточных системных процессов. Применялся контент-анализ, коллокейт анализ и данные, полученные из базы известных и предполагаемых взаимодействий биомолекул. Было выделено четыре результирующие фотоактивации светом видимого диапазона тригерзависимых системных процессов живой клетки: соразмерность триггеров с длиной волны; частотно-резонансная активация/деактивация; обусловленный поляризацией рост энергии светового потока; асимметричный ответ живых систем. Показано, что физико-химические особенности биополимеров обусловливают возможность проведения коррекции тригерзависимых процессов, а асимметричность ответа живых систем суммарно с увеличением поступления в систему энергии приводит кактивации механизмов, направленных на выживание.
\end{abstract}

Ключевые слова: триггер, системная биология, асимметрия, электромагнитное излучение, мишень.

\section{PHOTOACTIVITY OF THE BIOMOLECULES AS A POSSIBLE FACTOR FOR CORRECTION OF TRGGER DEPENDENT SYSTEMS PROCESSES} (FIRST REPORT)

\author{
O. P. Mintser, D. V. Vatlitsov \\ Shupyk National Medical Academy of Postgraduate Education
}

\begin{abstract}
The usage of a systemic approach for the investigation of the conceptual questions of the regulation and impact on certain link create the conditions for accumulation and take into all of the known results of numerous studies. Using this approach
\end{abstract} (ㄷ) О. П. Мінцер, Д. В. Ватліцов 


\section{МЕДИЧНА ІНФОРМАТИКА TA IHЖЕНЕРІЯ}

were re-evaluated the targets of electromagnetic radiation of UV, visible and infrared spectra for correction of intracellular systems processes. The aim of this work was to create a concept of trigger biomolecules photoactivation of living cells as a correction factor of intracellular systems processes. Were used the content analysis, collocate analysis and the data obtained from the database of known and predicted biomolecules and interactions. It was developed the four resulting of light on trigger dependent systems processes of living cells: size; resonance; increasing of luminous flux power after polarization; asymmetric response of living systems. It was shown that physical and chemical properties of the biopolymers caused the possibilities for correction of trigger dependent processes and asymmetric response of living systems to the increase in total energy uptake to the system leads to activation of survival mechanisms.

Key words: trigger, systems biology, asymmetry, electromagnetic radiation, target.

Вступ. Кожний проміжок часу в кожній живій клітині організму відбувається незліченна кількість процесів, що є основою природного існування живих систем [1]. На сьогодні класичні методи вивчення біологічних об'єктів майже вичерпані. Запропоновано нові підходи до розгляду проблем регуляції та концептуального впливу на певні ланки процесів із застосування інструментів системної біології [2-4].

Системний підхід до проблем розуміння сприйняття складності регуляції всіх реакцій в клітині $\epsilon$ викликом сучасному науковому товариству, оскільки головним є впровадження принципів холістичного підходу до вивчення біологічних об'єктів. Це принципово новий підхід, основою якого $\epsilon$ накопичення та врахування всіх відомих результатів численних досліджень [3, 5].

У даному контексті слід 3 іншого боку оцінити мішені електромагнітного опромінення УФ, видимого та ІЧ спектрів. Основою $є$ вибірковий вплив електромагнітних хвиль певної довжини на специфічні фотоактивні біомолекули. Існує незліченна кількість наукових робіт, що вказують на існування фотоактивності біологічних структур та біомолекул [6-10].

Вивчаючи ефекти фотоактивності автори відмічають, що визначальну роль відіграє селективна відповідь активних структур та біомолекул клітини на світлове опромінення, що мають, в даному випадку, ознаки тригерів $[11,12]$ системних клітинних процесів.

Мета роботи: формування концепції фотоактивації тригерних біомолекул живої клітини як фактора корегування внутрішньоклітинних системних процесів.

Матеріали та методи дослідження. Стратегія пошуку літератури і аналіз виконано згідно з раніше опублікованими рекомендаціями [13]. Публікації відбирали за релевантністю згідно пошукових запитів «photoactivity» за період 10 років (з 2005 по 2015 р.) у пошуковій системі PubMed, було виявлено 574 публікацій. Запит було деталізовано до- даванням «systems biology», що дозволило виявити 2 роботи. Резюме всіх публікацій були досліджені на наявність необхідної інформації. Застосовували формалізований метод вивчення текстової та графічної інформації - контент-аналіз [14]. Також використовували методи об'єднання, зіставлення i вивчення даних згідно $з$ пошуковими запитами, заснованими на поняттях, близьких за змістом до вихідних, що включали висновки як дослідника, так і інформанта - коллокейт аналіз [15].

Уявлення про тригери динамічних живих систем формували використовуючи бази відомих та передбачуваних взаємодій біомолекул pantherdb.org [16], UniProt [17] та stitch.embl.de [18] та за допомогою програми CellDesigner 4.4 .

Результати та їх обговорення. Інтерес до динамічних систем тригерного типу обумовлений, перш за все, специфічною для них наявністю двох станів стійкої рівноваги, завдяки яким система може як завгодно довго перебувати в одному 3 двох станів, стрибкоподібно перемикаючись із одного в інший під впливом зовнішньої та внутрішньої дії. Використання тригерних форматів дає можливість отримати стратегічні висновки підходів при поясненні ключових проблем життя та загибелі організму [11].

Відповідно до результатів проведених досліджень нами виокремлено чотири результуючі фотоактивації світлом видимого діапазону тригерзалежних системних процесів живої клітини:

1) співрозмірність тригерів 3 довжиною хвилі;

2) частотно-резонансна активація/деактивація;

$3)$ обумовлене поляризацією зростання енергії світлового потоку;

4) асиметрична відповідь живих систем.

Співрозмірність 3 довжинами хвиль УФ та видимого діапазону спектра та будова забезпечують хромофорність білків 3 поглинанням енергії світлового потоку. Співрозмірність підтверджується дифракцією світлових променів в розчині і формуванням світлового конуса Тіндаля-Фарадея [9].

Середня довжина протеїнів людини складає 476 амінокислот ( 5,5 нм) (рис. 1) (гідродинамічний 
радіус $\approx 5,5$ Нм), тоді як медіана 350 амінокислот $(\approx 4,9$ Нм) Наприклад енолаза 434 амінокислоти $(\approx 5,2$ HМ $)$, піруваткіназа 522 амінокислоти
( $\approx 5,6$ HM), EF-2/EF-G 855 амінокислот ( $\approx 6,5$ нM), результати представлені щодо гідродинамічного радіусу молекул.
Hexameric Human Insulin (34.2 kDa)
\[ \mathrm{R}_{\mathrm{H}}=2,7 \mathrm{~nm} \]

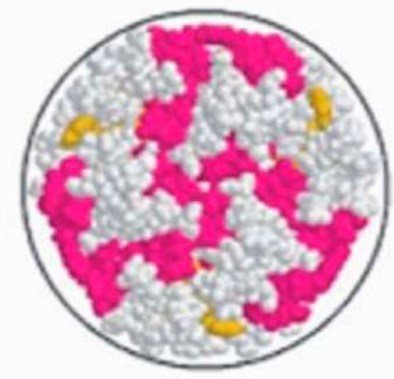

Immunoglobulin G (160 kDa) $\mathrm{R}_{\mathrm{H}}=7,1 \mathrm{~nm}$

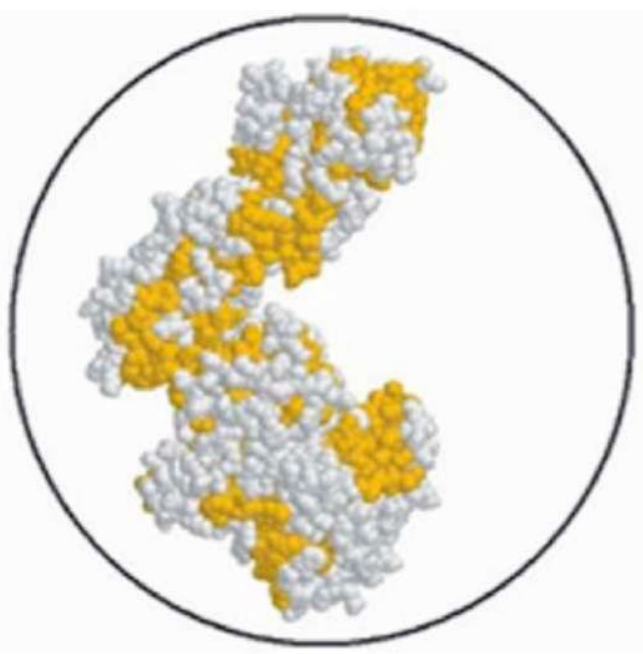

Hen Lysozyme $(14,7 \mathrm{kDa})$ $\mathrm{R}_{\mathrm{H}}=1,9 \mathrm{~nm}$

Puc. 1. Гідродинамічний радіус пептидів: інсулін, імуноглобулін G та лізоцим [8].

Наступним етапом дослідження стало вивчення можливої фотоактивності макромолекулярних комплексів, наприклад апоптосоми (маса більше 1 МДа та розмір $\approx 27$ HM), хлоридний канал 827 амінокіслот $\approx 6,5$ н M), RND 1296 амінокислот ( $\approx 7,5$ нM). метал іонний транспортер 692 амінокислоти $\approx 6,1 \mathrm{HM})[19,20]$.

Надкритичною $є$ модифікація інформаційних молекул. Тому важливим виявилося оцінювання ризиків нерегульованого впливу на ДНК та РНК. Оцінюючи ці молекули як мішені було встановлено, що довжина РНК складає від декількох сотень нуклеотидів до кількох тисяч, при довжині одного нуклеотида $\approx 0,34$ нм, а довжина ДНК в хромосомі людини в середньому дорівнює $\approx 4$ довжина хромосом варіює від 0,2 до 50 мкм.

Розміри внутрішньоклітинних структур перевищують довжини хвиль видимого спектра. Середній діаметр мітохондрій складає 1 мкм, тоді як рибосоми мають 20 нм завширшки, цитоматрикс має довжину волокон, співрозмірну 3 розмірами клітини, в середньому 100 мкм, проте товщину 2 - 3 нм [21].

Проведені дослідження виявили варіативність розміру клітинних, субклітинних та молекулярних структур, що обумовлює селективну фотоактивність співрозмірних молекул. Проте підтверженим $\epsilon$ той факт, що наявність пептидного зв'язку та залишків ароматичних амінокислот спричинює поглинання світла 3 довжиною хвилі 190 нм, трип- тофан, тирозин, фенілаланін, гістидин та сірковмісні амінокислоти $\epsilon$ причиною поглинання світла 3 довжиною хвилі 220 нм. Враховуючи довжину хвиль видимого світла та велику варіативність мішеней слід зазначити, що підбір індивідуальної монохроматичної довжини хвилі під певні умови застосування на данний час виконати неможливо. Проте вивчаючи структуру та способи передачі сигналів за умови активації певних тригерів слід запропонувати використання двох типів фотоактивації. Перший - це використання спектрального покрокового опромінення, тобто проведення спектрального опромінення 3 певним кроком в 1 нм, або застосовування поліхроматичних низькоенергетичних світлових потоків [9].

Два фактори вказують на правильність наших припущень :

1)наявність мішені фотоактивації в кожній окремо взятій клітині складає статистично малодостовірну величину, що нівелюється застосуванням повноспектрового опромінення задля фотоактивації тригерів системних клітинних процесів;

2) пролонгованість експозиції створює умови для передачі сигналу до кінця.

Частоти коливань білкових молекул знаходяться в діапазонах $10^{12}-10^{13}$ Г, а ІЧ та видимого спектрів від $1,5 \cdot 10^{12}$ до $0,79 \cdot 10^{13}$, що є підставою до висунення гіпотези щодо частотного резонансу [22]. Надмала проникна властивість природного розсіяного світла не створює достатніх умов для передачі ініціюючої 
кількості енергії, проте поляризація світла збільшує проникну здатність та потужність світлового потоку видимого діапазону й створює умови для передачі енергії фотонів (1,68 еВ - 3,26 еВ) тригерам.

Виходячи зі спостережень за розвитком життя на землі можна відмітити існування потужних механізмів, направлених на виживання організму, навіть за рахунок деяких важливих функцій, а інколи навіть цілих частин організму. Це створює підгрунтя для висунення теорії про еволюційно обумовлену асиметричність відповіді живих систем на подразник.

Висновки. Фотоактивність тригерних біомолекул може спричиняти їх «перезавантаження» та «перенапруження» термінальних ланок.

\section{Література}

1. Molecular cell biology / ed. H. F. Lodish. - New York : W. H. Freeman and Co, 2013.

2. Gunawardena J. Models in systems biology: the parameter problem and the meanings of robustness / J. Gunawardena // Elements of computational systems biology. - 2010. - Vol. 1.

3. Ghosh S. Software for systems biology: from tools to integrated platforms / S. Ghosh, Y. Matsuoka, Y. Asai[et al.] // Nature Reviews Genetics. - 2011.

4. Weaving knowledge into biological pathways in a collaborative manner/Y. Matsuoka, K. Fujita, S. Ghosh, H. Kitano // Computational Systems Toxicology / J. Hoeng, M. C. Peitsch. - New York, NY : SpringerNew York, 2015. - P. 181-208.

5. Asai Y. A versatile platform for multilevel modeling of physiological systems: sbml-phml hybrid modeling and simulation / Y. Asai, T. Abe, H. Oka[et al.] // Advanced Biomedical Engineering. - 2014. - Vol. 3, No. 0. - P. 50 58.

6. Schmid F.-X. Biological macromolecules: uv-visible spectrophotometry / F.-X. Schmid // eLS. 2001.

7. Benz R. W. Diffraction-based density restraints for membrane and membrane-peptide molecular dynamics simulations / R. W. Benz, H. Nanda, F. Castro-Roman [et al.] // Biophysical Journal. - 2006. - Vol. 91, No. 10. P. 3617-3629.

8. Arzensek D. Dynamic light scattering and application to proteins in solutions / D. Arzensek. - 2010. - P. 1-18.

9. Супрун А. Д. Теоретичні основи фізики функціонування білків / А. Д. Супрун // Київський національний ун-т імені Тараса Шевченка. - 2010.

10. Study of protein hydrodynamics with light scattering: size and charge of lysozyme / Y. Zhang, E. Farrell, D. Mankiewicz, Z. Weiner.

11. Мінцер О. П. Щодо межі доцільності використання поняття «тригерні взаємодії» у біології та медицині. перше повідомлення - постановка проблеми / О. П. Мінцер, К. М. Ігрунова // Медична інформатика та інженерія. 2014. - № 4. - Р. 14-22.
Фізико-хімічні особливості біополімерів обумовлюють можливість проведення корекції тригерзалежних системних процесів клітини електромагнітним опроміненням видимого та ІЧ спектрів. Визначення комбінацій «тригер» - «електромагнітне опромінення» дасть змогу таргетної корекції внутрішньоклітинних процесів.

Асиметричність відповіді живих систем $\epsilon$ наслідком еволюційного пристосування до змінення зовнішніх чинників, сумарно зі збільшенням надходження до системи зовнішньої, недепонованої енергії призводить до активації механізмів, направлених на виживання.

12. Мінцер О. Онтологічна модель процесів програмованої клітинної загибелі / О. Мінцер, Д. Ватліцов // Медична інформатика та інженерія. - 2015. - № 2. - Р. 14-26.

13. Methods for comparing data across differently designed agronomic studies: examples of different meta-analysis methods used to compare relative composition of plant foods grown using organic or conventional production methods and a protocol for a systematic review/K. Brandt, D. Srednicka-Tober, M. Baranski[et al.] // Journal of Agricultural and Food Chemistry. - 2013. - Vol. 61, № 30. - P. 7173-7180.

14. Writing@csu / [Електронний pecypc] http://writing. colostate.edu.

15. Mello R. A. Collocation analysis: a method for conceptualizing and understanding narrative data / R. A. Mello // Qualitative research. - 2002. - Vol. 2, № 2. - P. 231-243.

16. Panther - gene list analysis / [Електронний ресурс] http://pantherdb.org/ .

17. Uniprot / [Електронний ресурc] http://www.uniprot.org/. 18. Stitch: chemical association networks / 2015 [Електронний ресурс] http://stitch.embl.de/cgi/show_input_page.pl ?UserId=JVpPzrmqaBsj\&sessionId=7Rj9WLk964bn.

19. Size comparisons among integral membrane transport protein homologues in bacteria, archaea, and eucarya / Y. J. Chung, C. Krueger, D. Metzgar, M. H. Saier// Journal of Bacteriology. - 2001. - Vol. 183, No. 3. - P. 1012-1021.

20. Proteopedia: a status report on the collaborative, $3 \mathrm{~d}$ webencyclopedia of proteins and other biomolecules / J. Prilusky, E. Hodis, D. Canner [et al.] // Journal of Structural Biology. - 2011. - Vol. 175, № 2. - P. 244-252.

21. Rcsb protein data bank - rcsb pdb /[Електронний pecypc] http://www.rcsb.org/pdb/home/home.do.

22. Netrebko A. V. Subglobular oscillations of protein molecules in water overdamped? / A. V. Netrebko, Yu. M. Romanovsky, A. Yu. Chikishev // 2003. - Vol. 6, № 13. - P. 827-838. 